\title{
The Relation of the Leaf-trace to the Formation of Compound Rays in the Lower Dicotyledons. ${ }^{1}$
}

\author{
BY
}

\author{
IRVING W. BAILEY, A.B., M.F. \\ Instructor in Forestry and Wood Technology at Harvard University.
}

With Plates XV-XVII and one Figure in the Text.

$\mathrm{T}$ HERE exists in the wood of dicotyledonous plants considerable variation in the size, shape, and structure of the radially disposed plates of parenchyma, commonly designated medullary rays. This diversity of structure is well illustrated by several well-known genera of the Cupuliferae. Alnus and Castanea, for example, are characterized by possessing numerous small linear or uniseriate rays, rays similar in form and structure to the small rays which are a distinctive feature of the wood of coniferous plants. Occurring with this type of ray, and in marked contrast to it, are the large fusiform masses of parenchymatous tissue, often called primary rays, which occur in Quercus. Fagus, like the oak, possesses both the small linear or uniseriate and the large multiseriate type of ray, and in addition smaller multiseriate rays which are graded in size between these two extreme types. Betula, Carpimus, Ostrya, and Corylus possess usually, in the mature wood, numerous bi- and tri-seriate rays, among which are to be found scattering rays of the linear type. Finally in the lower Cupuliferae, Alnus, Betula, Carpinus, and Corylus, bands or aggregations of uniserate rays occur, and have been described by certain writers as 'false rays'.

The occurrence of 'false rays' in sections of a fossil oak from the gold gravels of California (Miocene) led Mr. A. J. Eames of this laboratory to investigate seedling and fossil oaks for evidence which might demonstrate what relation, if any, existed between the large multiseriate rays of living oaks and this 'false ray' of the Miocene oak. At the same time the writer carried on a series of investigations upon the distribution and origin of the 'false' and the large multiseriate rays in the Cupuliferae and other

1 Contributions from the Phanerogamic Laboratories of Harvard University, No. 27 .

[Annals of Botany, Vol. XXV. No. XCVII. January, I9I1.] 
families of dicotyledonous plants. The result of both investigations has shown that the large type of ray, normally found in living oaks, has been developed by the gradual aggregation and fusion of a number of small uniseriate rays.

The genus Almus offers a particularly illuminating illustration of the steps by which the large multiseriate ray has been 'built up' by an aggregation and fusion of numerous smaller rays. The evidence which demonstrates this process of fusion occurs abundantly, both in the distribution of ray structures in the various species of the genus and in the life-history of the individual plant.

In Pl. XV, Figs. I and 2, tangential and transverse sections respectively of the mature wood of Alnus acuminata, H. B. K. (A. oblongifolia, Torr.), is shown a type of wood in which there is an entire absence of any tendency towards aggregation of the uniseriate rays. In marked contrast to this condition is that illustrated in Figs. 3 and 4 , tangential and transverse sections of the mature wood of $A$. incana, (L.) Moench. In the central portion of the transverse section the entire absence of vessels from a band of tissue may be noted, and the uniseriate or linear rays are seen to be slightly approximated in this region. However, the tendency towards aggregation of the uniseriate rays is more clearly shown in the central portion of the tangential section, which should be examined with a pocket lens to demonstrate this feature more strikingly. In Figs. 5 and 6 a higher step of the compounding process may be seen in the mature wood of $A$. rubra, Bong. (A. oregona, Nutt.). Many of the aggregating rays have increased in size from uniseriate to bi- and tri-seriate, and are beginning to coalesce in places. Figs. 7 and 8 show an advanced step in the mature wood of A. maritima, (Marsh) Muehl. The aggregating mass has taken on the fusiform outline of a large oak ray, as may be seen in the tangential section, and is rapidly becoming a homogeneous mass of ray tissue, by the aggregation and fusion of the enlarged uniseriate rays, as well as by the transformation into parenchyma of fibres included in the coalescing mass of tissue. A completely fused aggregate or compound ray is illustrated in Fig. 9, a tangential section of the mature wood of $A$.rhombifolia, Nutt. This ray, upon comparison with the oak ray shown in Fig. I I, a tangential section of the mature wood of Quercus rubra, L., is seen to be homologous with the large multiseriate rays which occur in all American oaks with deciduous foliage. The transverse section of $A$. rhombifolia, shown in Fig. 10, is seen to illustrate a condition intermediate between those shown in Figs. 7 and 9. The transformation process has been completed on the left side of the aggregate ray, whereas the right side is still in incompleted stages of fusion. The elements which cross the axis of the ray diagonally are fibres in process of parenchymatization. This series of figures illustrates the development of the large compound ray from the uniseriate condition, but a great 
number of intermediate steps of transformation exist between these characteristic ones picked to demonstrate the main steps of the compounding process.

The evidence derived from the study of the development of ray structures in the life-history of the individual alder plant affords as conclusive a demonstration of the mode of development of aggregate or compound rays as does the comparative study of ray structures in the mature wood of distinct species of the genus Alnus. In the early stages of the development of the plant primitive stages of compounding and fusion occur, and with subsequent growth more highly perfected stages of aggregation are progressively developed. Thus in the first-formed annual rings of the seedling plants of certain alders non-aggregated uniseriate rays occur exclusively, but in subsequently formed rings radiating bands of tissue arise, which are characterized by congeries of uniseriate rays and by the absence of vessels. In the radial extension of these aggregate rays during many years' growth progressively higher stages of compounding occur, such as have been illustrated in Plates XV and XVI. As in recent years, through the researches of Strasburger, Goebel, Jeffrey, Jackson, and others, the importance of seedling plants in the recapitulation of ancestral characters has become a firmly established canon of comparative anatomy, the evidence afforded by the examination of these alder seedlings is an important guide to the phylogenetic history of the development of aggregate or compound rays.

It is of interest to compare the condition just described in the genus Alnus with that which occurs in oak. Upon the examination of material of a large number of American oaks the interesting fact was discovered, that in most species of American Live Oaks the so-called 'false ray' occurs in a more or less advanced stage of development towards the large compound ray, characteristic of oaks with deciduous foliage. In Figs. 12 and I 3 may be seen tangential and transverse sections of Quercus virginiana, Mill. (Q. virens, Ait.), the common Live Oak of the southern United States, which has reached a compounding stage similar to that seen in Alnus rubra in Fig. 5. Among other Live Oaks stages may be found in which fusion is even less well developed, and many advanced stages occur in the transformation of the aggregating into the broad, homogeneous type of ray. Strong evidence of the development of the large rays by a compounding process also exists in the American White and Red Oaks. Included fibres and wood parenchyma cells, vestiges of a compounding process, occur in the rays and display good evidence of their gradual transformation into ray parenchyma. A striking piece of evidence in this connexion is the fact that, whereas crystal cells are found abundantly in the large rays and in the wood parenchyma of many species of oak, these crystals are absent or extremely rare in the uniseriate rays. The presence of crystals in the large 


\section{Bailey.-.. The Relation of the Leaf-trace to the Formation of}

rays is most easily accounted for on the basis of the inclusion in them of what was originally wood parenchyma. In the Live Oaks the stages of the process by which the crystal-bearing wood parenchyma cells are fused into the compound or aggregate rays may be seen clearly. Furthermore, as in the case of alder, seedling plants afford interesting evidence in regard to the phylogenetic history of the development of ray structures in oak. Eames ${ }^{1}$ has pointed out that seedling White Oaks possess in their early wood only the primitive type of ray, the uniseriate ray. In subsequently formed layers the large homogeneous ray of the mature wood is formed by an aggregation and fusion of small rays and included fibre and wood parenchyma cells. The seedling Black Oaks display similar progressive stages of compounding (see Fig. I5), but in these oaks the aggregating tissue extends back to the earliest formed wood, indicating that the aggregate ray is more firmly established in the plant in this sub-genus. In contrast to this, in the early formed wood of the mature twigs of the Live Oak, there exist conditions similar to those which occur in seedling White Oaks, except that the aggregate ray develops further from the pith, and passes through the early stages of compounding less rapidly. Fig. 26 illustrates a twig of Live Oak in transverse section. The four aggregate rays at the top of the figure can be seen to originate in the central part of the section, and from the radius of curvature of the rings it can be seen that several years' growth intervene between the pith and the point where the aggregations originate.

Additional evidence of the formation of the large rays in oak by a compounding process has been pointed out by the writer in an article cited below. ${ }^{2}$ In this article it is shown that the wounded wood of mature oaks may revert to primitive stages of compounding in the ray. Since, in recent years, it has become an established principle that traumatic areas may be the seat of reversion to primitive characters, the study of wounded regions in oak supplies valuable evidence in regard to the phylogenetic development of ray structure. Rays immediately external to the traumatic areas are uniseriate, but in passing out from the wounded area (see Fig. 14) there occur all the steps by which the small rays are aggregated and transformed into a homogeneous mass of ray parenchyma.

From the palaeobotanical evidence afforded by Miocene oaks with ' false rays ', taken into consideration with that afforded by seedling plants, traumatic areas, and the distribution and development of compound rays in several genera, we see that primitive oaks and alders possessed only uniseriate rays. With the necessity for a large food reserve and storage system, due to the development of unequal seasonal temperature and rainfall

1 Eames, A. J. : On the Origin of the Broad Ray in Quercus. Bot. Gaz., xlix, March, I9Io, No. 3, pp. $16 \mathrm{I}-7$.

${ }^{2}$ Bailey, I. W.: Reversionary Characters of Traumatic Oak Wood. Botanical Gazette, November, I9I0. 
in later geological times, broad rays have been built up to meet this demand by a process of aggregation and fusion of numerous small uniseriate rays.

The evidence of the origin of large rays by a compounding process is not confined alone to the genera described above, but is amplified by a study of the development of ray structures in the life-history of certain species of Betula, Carpinus, Corylus, and Ericaceous and Rosaceous forms. In this connexion it should be noted that the aggregate ray, which was once apparently well developed, has been reduced in Castanea and certain Betulaceae and Ericaceae, and occurs in general only in portions of the plant which are known to reflect primitive characters. Several interesting features of this retrograde movement will be considered by the writer in a subsequent article.

It is of special interest to study the important part that the leaf-trace has taken in the origin and development of the type of ray under consideration in this article. This feature may be seen in small twigs of certain Fagaceae and Ericaceae in which the compounding rays are of more or less infrequent occurrence. These twigs show, upon the removal of the bark, that the aggregate rays occur in the form of longitudinal plates of tissue extending above and below the minute burls which occur at the node. These burls are disturbances formed through several of the first-formed annual rings, and are produced by the lateral and median traces of the leaf. In older and thicker twigs the aggregate rays are more numerously developed, and grouped in the nodal region. Obviously, the most accurate method of determining the exact relation of the leaf-trace to the compounding rays is the examination of transverse and tangential serial sections through the node. The writer, adopting this method, has constructed serial sections of the nodes of the Cupuliferae, Ericaceae, and other families of dicotyledonous plants. The transverse sections were constructed starting from a point well below the node and passing through the node, and to a considerable distance above it. Similarly, tangential serial sections were constructed through several annual rings to the pith. By the use of this method it was seen that the leaf-trace, in its passage outwards to the leaf, produces a disturbing effect upon the surrounding woody tissue. This is expressed by a diminution of the number of vessels and by the increase of storage tissue, particularly by the enlargement and multiplication of the rays. The extent to which parenchymatous tissue is developed about the entering leaf-trace varies with different species. In Castanea, Ostrya, and in certain alders and birches it is confined to the immediate vicinity of the leaf-trace, whereas in woods with well developed aggregate rays a large amount of storage tissue occurs above and particularly below the leaf-trace, as well as in radial extension beyond it. In Fig. I7, a transverse section of a small twig of Alnus temiifolia, Nutt., is illustrated the condition in which lateral leaf-traces (marked $x$ ) produce in their vicinity a slight tendency for the exclusion of 


\section{Bailey.-The Relation of the Leaf-trace to the Formation of}

vessels and the aggregation of rays, but this influence dies out radially after a few years' growth, and extends only slightly above and below the leaf-trace. In contrast to this, in the cross-section of a small twig of $A$. iaponica, Sieb. et Zucc., seen in Fig. I 8, strongly developed aggregate rays (marked $x$ ) extend outwards from the lateral leaf-traces and extend vertically many centimetres below them. Owing to this extension of the compounding tissue below the trace, a section at the node shows, in addition to the aggregate rays which are related to the leaf-traces of this node, other compound rays which are related to the lateral and median traces of higher nodes. One of the lateral traces illustrated in Fig. I 8 is seen under higher magnification on Pl. XVI. Fig. I9 shows the leaf-trace bundle and associated tissue below the node. The band of associated tissue extends in a radial direction towards the inner bark, and from it vessels are gradually disappearing. Fig. 2 I illustrates the same trace bundle as it passes off to the leaf. Vessels have entirely disappeared from the associated tissue, and the uniseriate rays have been gradually approximated and increased in number. As the leaf-trace bundle moves outward a gap is left in the protoxylem elements of the central cylinder. Fig. 23 illustrates the associated aggregate tissue which extends above the leaf-trace. The gap left by the departure of the leaf-trace is marked by the absence of protoxylem elements, and the aggregate ray extends to this, and, in consequence, apparently originates at the pith. A tangential view of $A$. japonica, showing the lateral leaf-trace and a small portion of the associated compounding tissue, is seen in Fig. 24. The associated aggregate ray is seen to be composed at this point of somewhat loosely approximated uniseriate and biseriate rays. In serial tangential sections, cut through many subsequent annual rings, progressively higher stages of aggregation and fusion occur. Figs. 20 and 22 illustrate the relation of aggregate or compound rays to the lateral leaf-traces of Quercus and Corylus. Fig. 29, a transverse section of Quercus velutina, Lam., shows a condition which occurs frequently in Almus, Betula, Carpinus, Ostrya, Quercus, and other genera, in which two or more aggregate rays are related to a single lateral leaf-trace. This condition occurs very frequently in tissue subtending the leaf-trace, whereas above the node there occurs usually but a single sheet of associated tissue.

The study of the leaf-trace in its relation to the origin and development of aggregate rays is very clearly shown in oak, as in this genus conditions exist which are extremely diagrammatic. The American Live Oak, Quercus virginiana, is of particular interest in this connexion, as it appears to retain primitive stages of the development of aggregate rays, and to indicate the influence which has made it advantageous for dicotyledonous plants to develop large storage systems in connexion with the leaf. Serial tangential and transverse sections, cut through the node of this oak, show that there is comparatively little specialized tissue above and below the leaf-trace during 
the first few years' growth, but during subsequent growth the quantity of parenchymatous storage tissue related to the leaf-trace is constantly increased until it extends a considerable distance below it. Fig. 28 illustrates the former condition; the associated compounding dies out a short distance below the leaf-trace. Fig. 30 illustrates the leaf-trace at some distance from the pith; a long aggregate ray, a small portion of which can be seen in the figure, now subtends the leaf-trace. In transverse sections, as may be seen in Fig. 26, the aggregate rays appear to originate at some distance from the centre of the stem, and only in sections cut in the immediate neighbourhood of the leaf-trace does the aggregate ray extend to the vicinity of the pith. The condition, which exists in the primitive Live Oak, indicates that, in all probability, with the development of unequal seasonal temperature and rainfall, parenchymatous storage tissue has been increasingly developed in the vicinity of the leaf-trace. This tissue has subsequently been increased in amount until highly specialized sheets of storage tissue or aggregate rays result in the mature portions of the plant. As might be expected, American oaks with deciduous foliage possess higher stages of the development of storage tissue in relation to the leaftraces. In seedling White Oaks, according to the law of recapitulation, a condition similar to that of the mature Live Oak stem exists. There is this difference, however, that although the rays do not extend to the pith above and below the leaf-trace, they pass through the stages of compounding abruptly, the phase of compounding being confined to one or two annual rings. In the mature stem of this sub-genus the lateral leaf-trace rays become gradually more firmly seated upon the plant, and originate in their internodal extensions in the vicinity of the pith. Fig. 25 illustrates the cross-section of a small twig of Quercus alba, L. It will be noted that there exists in oak a five-lobed pith. At each node a median trace passes off from the extremity of one lobe, and two lateral traces from the sides of the adjoining lobes. As more or less persistent aggregate rays are associated with the lateral traces, a section of the stem possesses usually ten aggregate rays which are grouped in pairs. Occasionally, however, aggregate rays develop in relation to the median traces, or one or more of the lateral traces may be abortive, in which case an odd number of compound rays exists in the cross-section, as is the case in Fig. 25. In the Red Oaks the aggregate rays are more firmly established upon the plant than is the case in the White Oaks. Thus, in seedling Red Oaks, as in the mature twigs of White Oaks, the associated tissue above and below the leaf-traces extends to the neighbourhood of the pith in the internode, as well as to the point at which the trace passes to the leaf. In mature twigs of Red Oak, as may be seen in Fig. 27, a transverse section of Quercus velutina, the tendency for the formation of aggregate or compound rays has become so firmly fixed upon the meristematic tissues that numerous rays, in addition to the charac- 


\section{Bailey. - The Relation of the Leaf-trace to the Formation of}

teristic lateral leaf-trace rays, originate in the early formed wood of the twig. In other words, when the aggregate ray becomes firmly established upon the plant, as in the older wood of Live and White Oak and in the early wood of Black Oak as well, aggregate rays which are but indirectly related to the leaf-traces develop to meet the demands of the increased circumference of the stem. Just as in the case of coniferous woods, new uniseriate rays are continually formed by the cambium, at progressively greater distances from the pith, to maintain the proper proportion of ray tissue in the widening stem.

In the development of compound rays in the Cupuliferae the lateral leaf-traces have played the most important part. For, although compounding is often related to the median trace or traces (three in Alnus, Carpinus, Corylus, and Ostrya), the location of the bud directly over the median trace has apparently produced a retarding influence on the development of compound rays in this region. However, in the Ericaceae, where no lateral traces occur, the median traces have been the sole factors in developing the compounding rays. The fact that the Ericaceae are without lateral traces probably accounts in part for the primitive stages of aggregation found in the wood rays.

We may sum up the relation of the leaf-trace to compound rays as follows. In the development of the large storage systems necessary to plants living in regions of markedly unequal seasonal temperature characteristic of later geological time, the origin of storage tissue about the entering leaf-trace has proved a natural starting-point for the formation of compound or aggregate rays. By a gradual development of the amount of special storage tissue, above and below the traces, and its extension outward with each annual layer of growth, a larger and larger food-reserve system has been developed, until in the higher types, by the transformation of the compounding tissue, consisting of aggregated small rays and separating fibres, into ray parenchyma, homogeneous masses of ray tissue have been produced. In less highly specialized species of the Cupuliferae the primitive stages of the development of aggregate rays and their relation to the leaftraces are clearly shown. In specialized species, in which the aggregate ray is firmly established, the phases of compounding and the importance of the leaf-trace, as the originating influence in the development of compounding, have been somewhat obscured except in the younger, seedling portions of the plant.

It is an interesting and important fact that in the development of the stem of plants which possess aggregate rays there is a marked difference between the general rate of growth of the woody tissues and that of the large aggregate rays. This is usually expressed by a strong 'dipping in' of the outline of the annual ring in the vicinity of the large ray. In other words, the compound ray produces usually a retarding influence upon 
growth in its vicinity. This condition is shown in the cross-sections illustrated in Figs. 4, 6, 8, and I0, and it may be noted in addition that the sag in the outline of the year's growth increases pari passu with the development of the ray. With higher phases of compounding and the increase in size of the ray, the 'dipping in' of the compound ray becomes more strongly developed. This retarding influence of the aggregate ray upon the growth of the stem is well marked in the twigs of the Blue Beech (Carpinus caroliniana, Walt.) and Betula pumila, L. When the bark is removed from small twigs of these plants it is seen that the woody cylinder appears strongly crenulated in outline. The aggregate rays in these species are of large size and strongly developed, and produce pronounced sags in the periphery of the stem. Individually the aggregate rays produce a retarding influence upon growth, and when approximated several aggregate rays produce a general dip in the outline of the stem by their co-ordinated retarding influence upon growth. This condition is well illustrated by the bole of the Blue Beech (Carpinus caroliniana). As is well known, this small tree is characterized by a strongly fluted stem. A cross-section of such a stem reveals the interesting fact that the furrows in the stem correspond to bands of numerous closely approximated compound rays, and the ridges to areas in which the rays are nearly absent. The stem of other members of the Betulaceae and of Quercus and Fagus often show a similar condition. Where the compound rays are approximated there is a corresponding depression in the outline of the stem. The most striking illustration of the retarding influence of aggregate rays upon the development of the woody cylinder occurs in the branches of White and Red Oaks, and in Clematis. As may be seen in Fig. 25, the stem appears to be divided into ten segments, five of which are larger wedge-shaped segments projecting beyond five smaller depressed segments with parallel sides. The sunken segments, as will be noted on closer inspection, are separated from the larger ones by the lateral leaf-trace rays which have been described earlier in this article. In fact, it is the strong retarding influence of this storage tissue, associated with the lateral leaf-traces and longitudinally relayed from node to node in ten vertical lines up the stem, which has produced the depression representing the smaller segments. Where the rays are strongly developed the segments are strongly depressed, and when the aggregate rays are feebly developed the segments are correspondingly slightly depressed. Similarly, when the ray on one side of a small section is slightly developed or absent, the segment is seen to be unsymmetrically developed. Thus in Fig. 25 one of the small segments is depressed upon the right side by the aggregate ray (marked $a$ ), whereas on the opposite side $(b)$, owing to the absence of a compound ray, the segment rounds up to the outline of the larger segment without well-marked sags in the annual rings, such as occur on the opposite side. A similar condition is shown in the lower portion of Fig. 27 ; the ray 


\section{$23+$ Bailey. - The Relation of the Leaf-trace to the Formation of}

at the left is at first feebly developed, and the segment is in consequence but slightly depressed upon the left side. In addition it should be noted in this figure that the segment becomes more strongly depressed as the aggregate rays become more firmly established in the older portion of the stem.

From this we see that the aggregate ray, as it possesses a different rate of growth from the rest of the secondary wood, has often a marked effect upon the development of the stem. This is expressed in most cases by a retarding influence upon growth, which produces a distinct sag in the outline of the annual rings in the vicinity of the large ray. The most striking illustrations of the effect of this retarding influence of the compound ray are seen in the fluted stem of the Blue Beech and in the depressed small segments of oak branches.

\section{CONCLUSIONS.}

The origin and development of aggregate or compound rays, as revealed by the study of the comparative anatomy and morphology of the Betulaceae
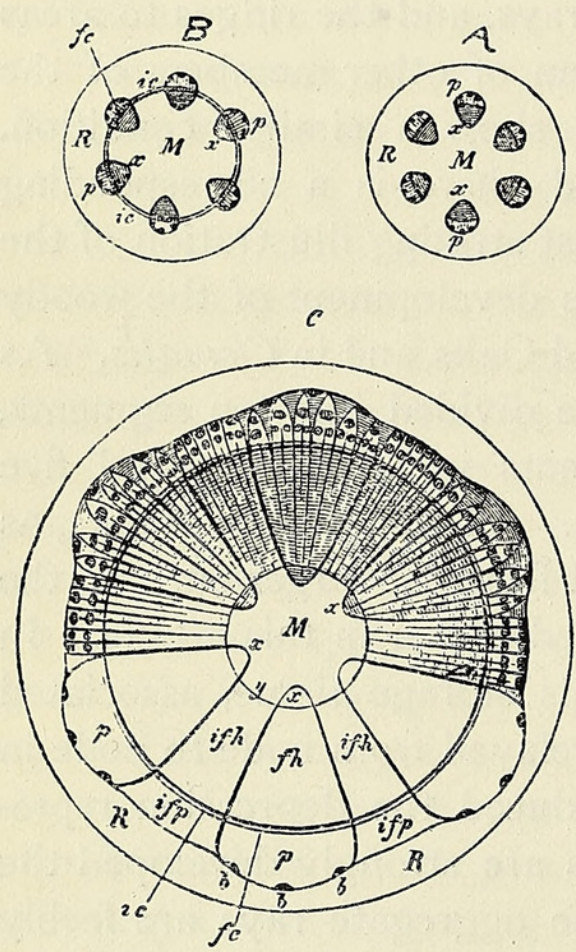

TeXT-FIG. - Description in text. and higher Cupuliferae, and by the phylogenetic evidence afforded by seedling plants and traumatic areas, is significant in a consideration of the development of the fibrovascular cylinder of woody plants. The theory of the origin and development of the central cylinder of Gymnosperms and Angiosperms has remained practically unchanged, in the botanical literature of the Old and New World, since the publication of Sachs' 'Lehrbuch der Botanik'. Subsequent authoritative writers have adopted the theory, and the Sachsian figures illustrating it have been largely copied by European writers, as well as by American writers. This conception, which appears to have really originated with Sanio and to have been exploited by Sachs and De Bary, may be summed up as follows, using the Sachsian figures as illustrations. In herbaceous plants and in the 'embryonic stem' of woody plants (see A), there is developed a ring of primary collateral bundles. These are arranged in a circle, thus dividing the fundamental tissue into two portions, a pith $M$ and a cortex $R$. Each open bundle possesses primary phloem, $p$, on the outside and primary xylem, $x$, on the inside, and these are separated by a meristematic tissue or fascicular cambium. In the development of 
trees, vines, and shrubs from this supposedly primitive condition, the fascicular cambiums of the bundles are extended in a tangential direction through the fundamental tissue enclosed between the bundles, or ' primary medullary rays' (see B). The fascicular cambiums are thus joined together, forming a cambium ring. The part of the cambium, $i c$, extending between the bundles is called interfascicular cambium in contrast to the cambium of the fascicular segments, $f c$. By the continual division of the cells of the cambium ring, secondary xylem is laid down on the inside of the ring and secondary phloem on the outside. Thus the primary phloem and xylem are forced further and further apart, and growth in diameter takes place. This condition is illustrated in $C_{3}$ in which $p$ and $x$ are the primary phloem and xylem, $f h$ the secondary xylem formed by the fascicular cambium, and if $h$ the tissues formed by the interfascicular cambium. It is to be noted that no primary xylem subtends the segments $i f h$. In the primitive condition the entire fundamental substance between the bundles is supposed to be kept continuous from the pith to the inner bark by the divisions of the interfascicular cambium. In more specialized forms more or less of the tissue formed by the interfascicular cambium is composed of lignified elements or secondary xylem, and the 'primary rays' are thus confined to more or less restricted radii of the interfascicular segments. It has also been supposed that arborescent and shrubby plants have been evolved from herbaceous forms by the gradual fusion of separate fibro-vascular bundles into a compact woody cylinder.

A serious objection to the hypothesis which we have just outlined is the fact that, although arborescent and shrubby forms are supposed to have been evolved from herbaceous forms, the lowest dicotyledonous plants possess well established woody stems, and herbaceous plants occur mainly among the higher families of the Dicotyledons. Similarly the arborescent or shrubby condition is a distinctive feature of Gymnosperms to the exclusion of the herbaceous type. If the woody Phanerogams have been evolved from herbaceous ancestors the latter must have entirely perished. There is, moreover, no undoubted palaeobotanical evidence to indicate that such herbaceous progenitors ever existed. In this connexion it is of interest to note that the surviving representatives of the aborescent palaeozoic Cryptogams are herbaceous or semi-herbaceous in habit.

Furthermore, in accordance with the Sachsian theory, it would be reasonable to expect that in the individual development of the most primitive living dicotyledonous plants, the earliest formed tissues, which by the law of recapitulation reflect the phylogenetic history of the plant, should possess anatomical characters resembling ancestral characters more closely than do those tissues which occur in the mature portions of the plant. In fact, according to the Sachsian hypothesis, in the development of the stem of woody dicotyledonous plants, the transition from a separate ring of 


\section{Bailey. - The Relation of the Leaf-trace to the Formation of}

bundles to a hollow woody cylinder is assumed to exist in the so-called 'embryonic stem'. This hypothetical condition, however, does not occur in woody plants, and the study of the development of seedling plants reveals the fact that in numerous species conditions exactly the reverse of those which should be expected in accordance with the Sachsian theory occur. The Cupuliferae illustrate the truth of this statement very clearly and diagrammatically. In the mature twigs of Red and White Oak there are, as has been shown in Fig. 25, five smaller depressed segments. These segments, and the rays which demark them, are considered interfascicular segments, and the aggregate rays are supposed to be continuations of portions of the fundamental tissue, included between the primary bundles. Furthermore, it has been supposed that masses of protoxylem subtend the larger, but not the smaller segments of the stem. However, we have seen above that seedling Red and White Oaks and the stem of the primitive Live Oak do not show this segmented character of the woody cylinder, but possess instead, in the first annual ring, a continuous woody cylinder. This unexpected condition is explained by a consideration of the origin and development of the large rays in oak. The so-called primary rays have been shown to originate in the vicinity of the leaf-trace, and to be formed from the secondary wood by an aggregation and fusion of numerous uniseriate rays and included fibres, and to be in no way related to inclusions of fundamental tissue between so-called primary bundles. As has been shown above, seedling plants elucidate the phylogenetic history of these ray structures, and illustrate the early stages of their development. In the mature portions of the plant the aggregate rays are seen to become highly perfected, and to extend considerable distances above, and particularly below, the leaf-traces. The depressed segments which occur in the mature twigs are, in reality, caused by the concentrated retarding influence of long lines of paired aggregate rays upon the growth of a portion of the stem. That these depressed segments do not correspond to tissue formed by an interfascicular cambium is further shown by the fact that they are subtended by protoxylem elements, similar to those which subtend the larger so-called fascicular segments. Similar conditions occur in other genera of the Cupuliferae. In fact the primitive central cylinder consists invariably of a continuous woody ring, and only with the development of highly specialized ray structures, in mature ramifications of the plant, does the central cylinder appear to originate from so-called fascicular and interfascicular segments. In Fig. $I 7$ is illustrated the primitive condition of the central cylinder in the Cupuliferae. The protoxylem elements form an unbroken line around the pith, and there is no indication of the division of the central cylinder into the putative fascicular and interfascicular segments. However, as the two lateral leaf-traces pass off in this section, it may be seen that a gap is left in the protoxylem elements of the central cylinder. In the 
species figured, which has only a slight amount of storage tissue associated with the leaf-trace, the foliar gaps are not persistent for any considerable distance above the node. In Fig. 18 , on the other hand, is illustrated an alder in which long lines of storage tissue have been developed in relation to the leaf-traces. Above the node the storage tissue extends to the more or less persistent and elongated foliar gaps. This relation of the aggregate rays to the leaf-traces, which is found in the more highly specialized Cupuliferae with large aggregate rays, produces in the stem a segmented appearance of the central cylinder which has been erroneously taken to indicate the origin of the woody cylinder from a ring of originally separate, so-called primary bundles. In Figs. 19, 21, and 23 the formation of the aggregate ray and its relation to the enlarged foliar gap is illustrated in Almus japonica by serial sections.

From this consideration of the origin and development of aggregate rays, and their modifying influence upon the primitive stele of the Cupuliferae, it appears that the Sachsian theory of secondary growth must be exactly reversed in order to agree with the anatomical evidence afforded by a comparative developmental and experimental study of the lower Dicotyledons. Furthermore, the general examination of the anatomy of fossil and extant plants reveals the fact that the primitive condition of the fibro-vascular system was a continuous hollow cylinder. Further, in the evolution of modern seed plants there has been a more or less pronounced reduction of the amount of primary xylem of the central cylinder. This reduction of the primary tissues has, in most cases, progressed unevenly along the inner circumference of the stele, and, as a result, in many cases well developed areas of primary xylem are separated by areas in which only traces of primary elements or none at all occur. In Angiosperms the primitive condition of the stele is a continuous tubular cylinder. This has been pointed out by Jeffrey ${ }^{1}$ in a study of the Ranunculaceae, Nymphaeaceae, and Saxifragaceae, by the writer, as has been shown in this article, in the Cupuliferae, and byEames, in an article which appears contemporaneously with this, in certain semi-herbaceous Rosaceae. In the development of the latest dicotyledonous plants, the protoxylem elements of the solid tubular cylinder have become gradually more or less localized, first into a primary ring with localized thickened areas, separated by areas from which the protoxylem has nearly disappeared, and finally into a dissected cylinder or ring of separate primary bundles. The origin and development of large sheets of storage tissue by the parenchymatization of certain radii of the secondary xylem, in connexion with the leaf, and the formation of elongated more or less persistent foliar gaps in relation to these structures, appear to have been the controlling factors in the localization of primary elements, and

${ }^{1}$ Jeffrey, E. C. : The Morphology of the Central Cylinder in Angiosperms. Trans. Canad. Inst., vol. vi, 1899 . 
in the dissection of the woody cylinder. By the development of these structures the woody cylinder becomes at first a network of xylem tissue filled in by large thin sheets of storage tissue. A higher step of this dissection process, in the Cupuliferae, may be seen in the mature twigs of Red and White Oak. In these highly specialized and diagrammatic stems, as also in Clematis, the aggregate rays formed by the leaf-traces at each node are relayed from node to node up the stem in long vertical lines. In these stems, therefore, the woody cylinder is actually divided into ten so-called fascicular segments, separated by sheets of vertically fused aggregate rays or interfascicular segments so called. Owing to the fact that the large rays are grouped in approximated pairs, five smaller segments are depressed by the concentrated retarding influence of these rays upon their growth. Among higher families of the Dicotyledons there exist still higher degrees of the dissection of the central cylinder by means of the parenchymatization of secondary xylem, in relation to the leaf. This expresses itself in the transformation of larger and larger segments of the central cylinder into parenchyma, and in the gradual decrease in thickness of the woody cylinder. The cylinder is thus split up into small segments or bundles, separated by broad radial stripes of parenchyma subtended by the so-called interfascicular cambium. In the progress of the herbaceous habit the interfascicular cambium also loses its activity. Eames, in an article which appears with this, has succeeded in demonstrating these progressive transitions in certain Rosaceous species. Thus, for example, the prostrate biennial or perennial stems of Potentilla palustris, as well as the seedling plant, possess an unbroken central cylinder, whereas the cylinder of the erect annual stem a short distance above the rhizome breaks up into a typically herbaceous stem.

From this consideration of the comparative anatomy of living and fossil plants, particularly of the Cupuliferae, of the phylogenetic significance of seedling plants, and of the origin and development of storage tissue in relation to the leaf-trace, we come to the conclusion that the Sachsian hypothesis of the origin of the central cylinder of woody plants, based upon appearances rather than upon an adequate study of anatomical facts, must be reversed in order to agree with actual conditions among the higher seed plants. The most striking feature of this study has been the important part that the leaf-trace has played in the development of complex ray structures, and in the development of the herbaceous habit.

In view of the confused terminology of ray structures which exists in botanical literature, it seems desirable at this point to endeavour to unravel this tangle in the light of recent investigation upon ray structure. All ray structures occurring in the xylem portions of plants have been commonly called 'medullary rays'. Inasmuch as these structures originate only with secondary growth, and are in no sense related to fundamental tissue, 
the term ' medullary' in this connexion appears to be inadmissible. It has been shown that the so-called 'primary' rays or aggregate rays are in no sense related to inclusions of fundamental tissue, but are produced with secondary growth by the aggregation and fusion of uniseriate rays, and by the parenchymatization of fibres separating these. Similarly the smaller multiseriate, bi- and tri-seriate rays, such as occur in Betula, Carpinus, Ostrya, and Fagus, are formed by the enlargement of individual uniseriate rays or by the dissection of aggregate rays. The primitive type of ray, the uniseriate ray, develops only with secondary growth, and is in no sense related to the medulla. This becomes very clear from a consideration of the comparative anatomy of living and fossil woody plants, particularly of the anatomy of plants which retain well developed primary structures. Fig. I6 illustrates a cross-section of Lyginodendron oldhamium. It will be noted at once that the rays which develop with secondary growth do not extend into the primary metaxylem at all, nor are they related in any way to the fundamental tissue of the pith. Similarly in living plants which retain well developed primary metaxylem, e.g. roots of certain Conifers, Larix and Abies, it can be seen that the rays originate only with secondary growth. It is only in more highly specialized plants, in which the primary structures have been much reduced, that the rays appear to connect with the medulla. In consequence it seems desirable to replace the term ' medullary ray' by wood ray in designating this parenchymatous tissue of the xylem. In the past it has been customary to divide ray structures into two classes, the so-called 'primary' and 'secondary rays'. As has been shown above, all zwood rays are essentially secondary, in that they originate only with secondary growth. However, if these terms are to be retained in botanical literature the term primary might well be applied to the primitive or uniseriate ray, and the word secondary to the larger rays which have been evolved from them. The large ray may be divided into two classes according to its mode of origin. The most important large rays are the compound, aggregate, or foliar rays whose origin has been described in this article. In addition there are certain smaller multiseriate rays, usually bi- or tri-seriate, which originate by the increase in size of uniseriate rays or by the dissection of aggregate rays. These might well be called multiseriate. There is strong evidence for believing that this type of ray has been produced, as has the aggregate type, in connexion with the leaf. However, this will receive further investigation in this laboratory.

In conclusion, I wish to express my sincere thanks to Professor E. C. Jeffrey for valuable assistance and advice in conducting this investigation. To my colleague in Forestry, Professor J. G. Jack of the Arnold Arboretum, I am indebted for much carefully identified green material of 
many species of woody plants, and to Mr. A. J. Eames for Figs. I2 and I5, and for the opportunity of examining serial sections of herbaceous and semi-herbaceous plants.

\section{DESCRIPTION OF PLATES XV-XVII.}

Illustrating Mr. Bailey's paper on Compound Rays in Lower Dicotyledons.

(It is suggested that a hand lens be used in the examination of the figures.)

\section{PLATE XV.}

Fig. I. Almus acuminata. Tangential section of the mature wood, showing non-aggregated uniseriate rays. $\times 40$.

Fig. 2. The same. Transverse section. $\times 40$.

Fig. 3. Alnus incana. Tangential section of the mature wood, showing in the central portion a band of aggregating uniseriate rays. $\times 40$.

Fig. 4. The same. Transverse section. $\times 40$.

Fig. 5. Alnus mbra. Tangential section of the mature wood, showing a higher step of the aggregating process in which the rays have increased in size to bi- and tri-seriate and are coalescing in places. $\times 4^{0}$.

Fig. 6. The same. Transverse section. $\times 40$.

Fig. 7. Alnus maritima. Tangential section of the mature wood, showing an advanced stage of the compounding process in which the coalescing mass has taken on the fusiform outline of a large oak ray, and in which the fibres included in the tissue are being transformed into parenchyma. $\times 40$.

Fig. 8. The same. Transverse section. $\times 40$.

Fig. 9. Alnus rhombifolia. Tangential section of the mature wood, showing a completely fused aggregate or compound ray which is composed of a homogeneous mass of parenchymatous tissue homologous to the large oak ray seen in Fig. I I. $\times 40$.

Fig. Io. The same. Transverse section of the wood, showing an intermediate step between those shown in Figs. 7 and $9 . \quad \times 40$.

Fig. II. Quercus mbra. Tangential section of the wood, showing the large aggregate ray which is characteristic of American oaks with deciduous foliage. $\times 40$.

Fig. I2. Quercus virginiana. Tangential section of the wood, showing a compounding condition similar to that seen in Almus rubra in Fig. 5. $\times 4^{\circ}$.

\section{PLATE XVI.}

Fig. I3. Quercus virginiana. Transverse section of the wood, showing aggregating tissue in which fibres and wood parenchyma cells are being transformed into ray parenchyma. $\times 40$.

Fig. 14. Quercus alba. Tangential section of traumatic wood, showing the reversion of wounded wood to primitive stages of compounding in the large rays. $\times 80$.

Fig. I5. Quercus velutina. Tangential section of the seedling plant, showing primitive compounding phase similar to that which occurs in the mature wood of Almus rubra and Quercus virginiana. $\times 40$.

Fig. I6. Lyginodendron oldhamium. Transverse section of the primary and secondary wood, illustrating the fact that the wood rays originate with secondary growth and do not extend into the metaxylem or have any relation to the fundamental tissue or medulla. $\times 20$.

Fig. 17. Alnus tenuifolia. Transverse section of a small twig, showing a primitive condition of the woody cylinder, which is seen to consist of a solid homogeneous tubular cylinder except at the points where the lateral leaf-traces $(\operatorname{marked} x$ ) and associated tissue are interposed. $\times \mathrm{I} 5$. 
Fig. 18. Alnus japonica. Transverse section of a small twig, showing a somewhat specialized form of central cylinder in which long sheets of aggregated tissue, in relation to the leaf-traces, have produced a segmented appearance of the stem. $\times 10$.

Fig. I9. Almus japonica. Transverse section of the stem below the node, showing a leaf-trace bundle and associated tissue from which the vessels are gradually disappearing. $\times 40$.

Fig. 20. Quercus alba. Transierse section of the stem, showing aggregating tissue associated with a lateral leaf-trace. $\times 40$.

Fig. 2I. Almus japonica. Transverse section near the node, showing the leaf-trace just starting out to the leaf, the foliar gap left in the primary cylinder, and the aggregating tissue related to the leaf-trace. $\times 40$.

Fig. 22. Corylus rostrata. Transverse section of the stem, showing the relation of an aggregate ray to the lateral leaf-trace. $\times 40$.

Fig. 23. Alnus japonica. Transverse section above the node, showing the relation of the aggregate ray to the persistent foliar gap in the primary woody cylinder. $\times 4^{0}$.

Fig. 24. The same. Tangential section of the wood, showing the aggregating tissue which occurs above and below the lateral leaf-traces. $\times 4^{\circ}$.

\section{PLATE XVII.}

Fig. 25. Quercus alba. Transverse section of a small branch, showing the five small sunken segments which are depressed by the retarding influence of the approximated lateral leaf-trace rays upon the growth of the stem. $x$ Io.

Fig. 26. Quercus virginiana. Transverse section of the stem, showing the aggregate rays which appear to originate at some distance from the pith. $\times 12$.

Fig. 27. Quercus velutina. Transverse section of the stem, showing a sunken segment and the retarding influence of the aggregate rays upon the growth of that portion of the stem. $\times I_{5}$.

Fig. 28. Quercus virginiana. Tangential section of the wood, showing the small amount of aggregating tissue that is associated with the lateral leaf-trace in the first-formed wood of the stem. $\times 60$.

Fig. 29. Quercus velutina. Transverse section of the stem, showing two aggregate rays related in origin to a single lateral leaf-trace. $\times 20$.

Fig. 30. Quercus virginiana. Tangential section of the wood at some distance from the pith, showing a portion of the long aggregate ray that is associated with the lateral leaf-trace. $\times 60$. 
Annals of Botany.
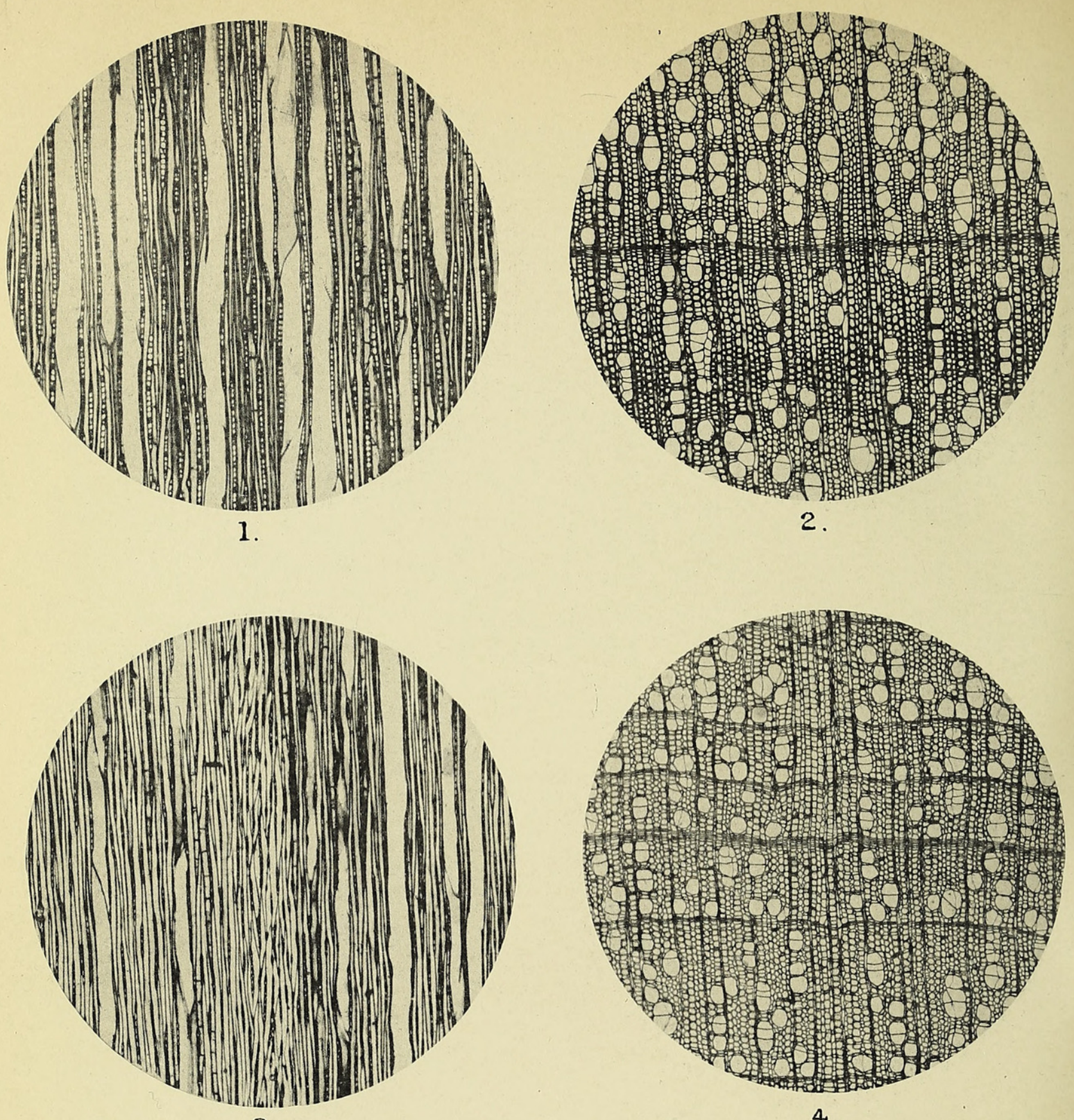

3.
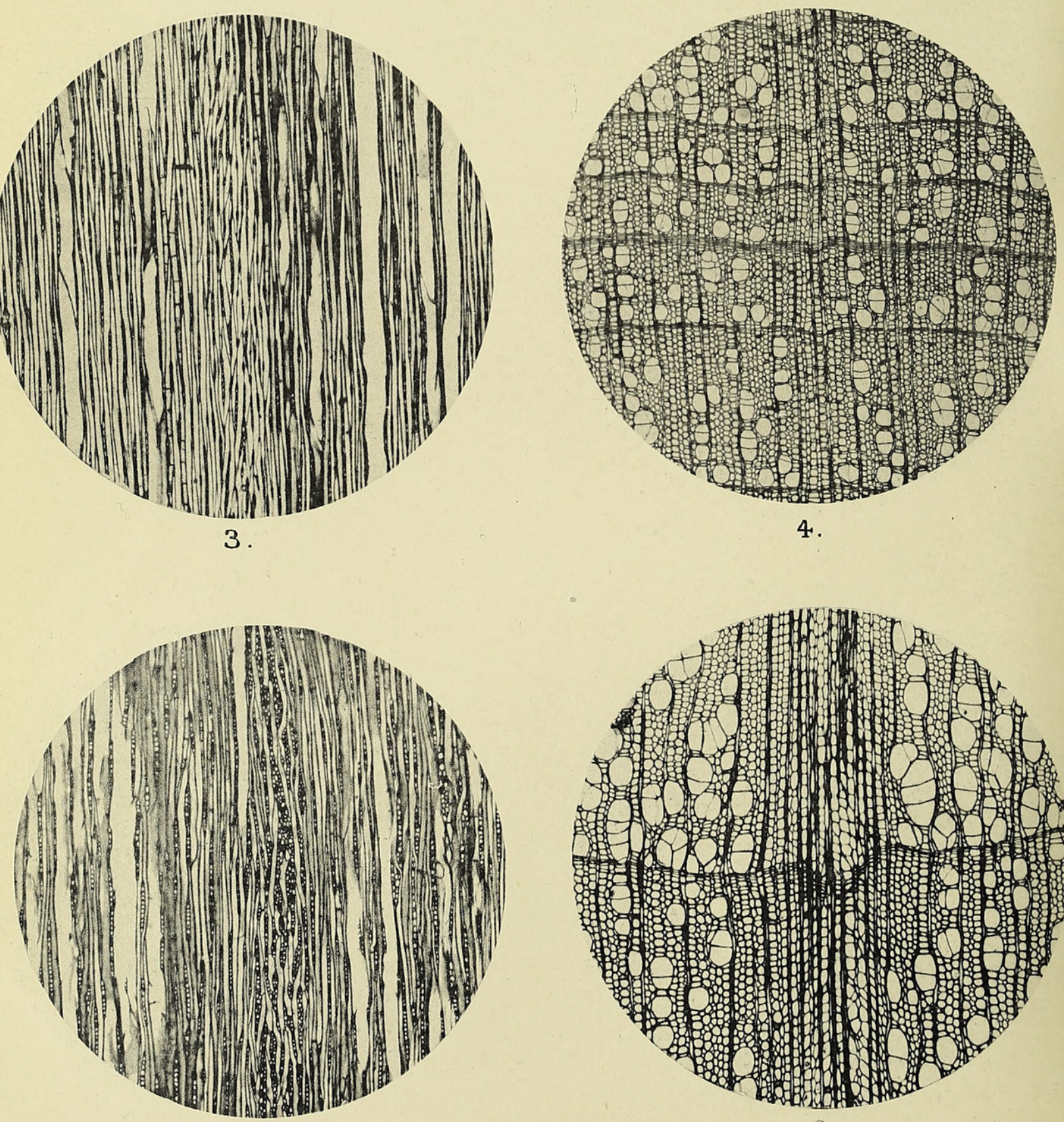

5.

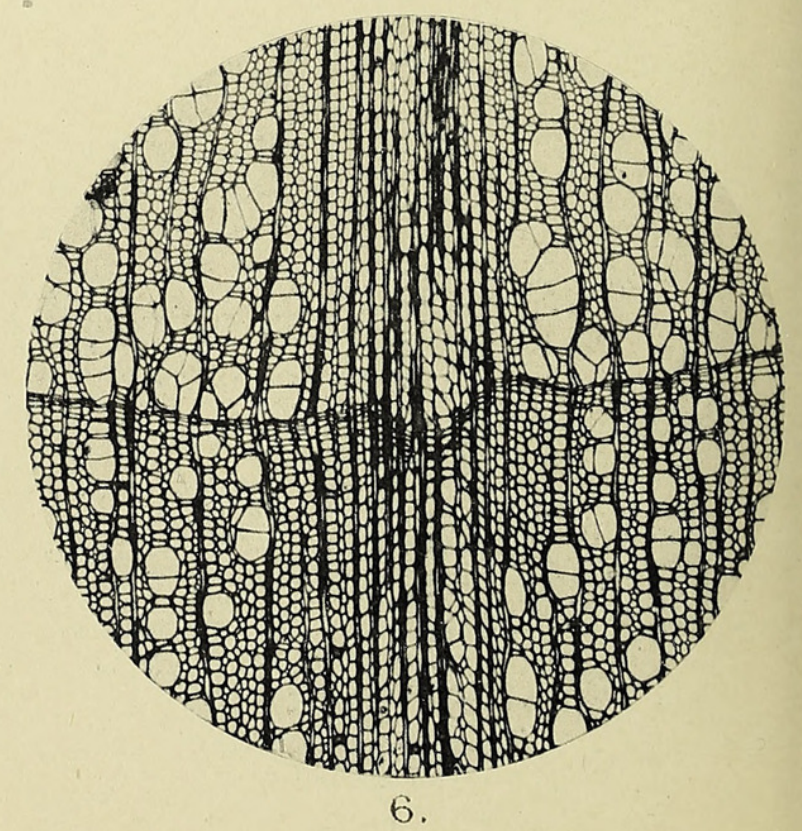




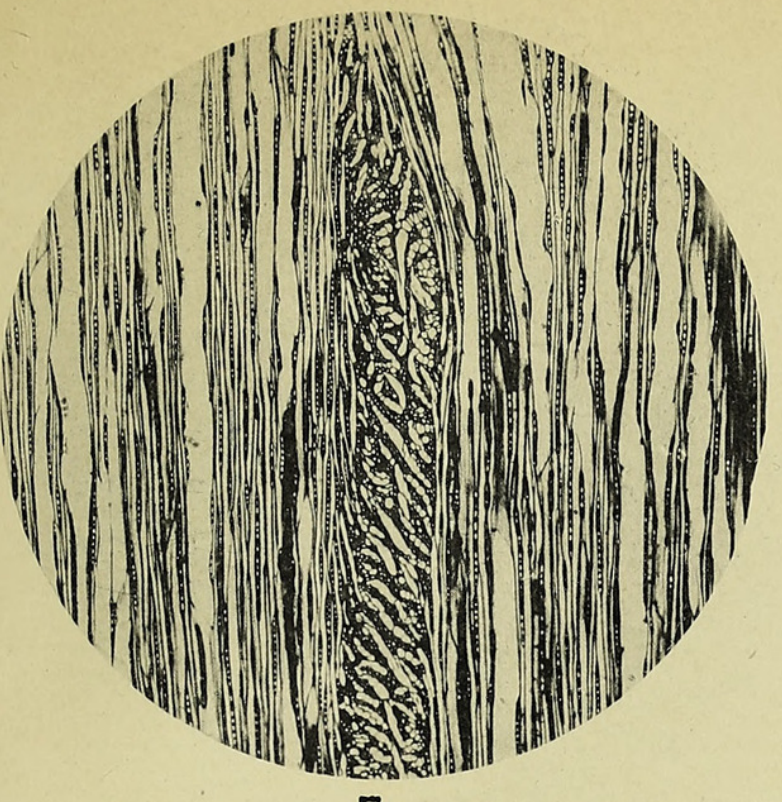

7.
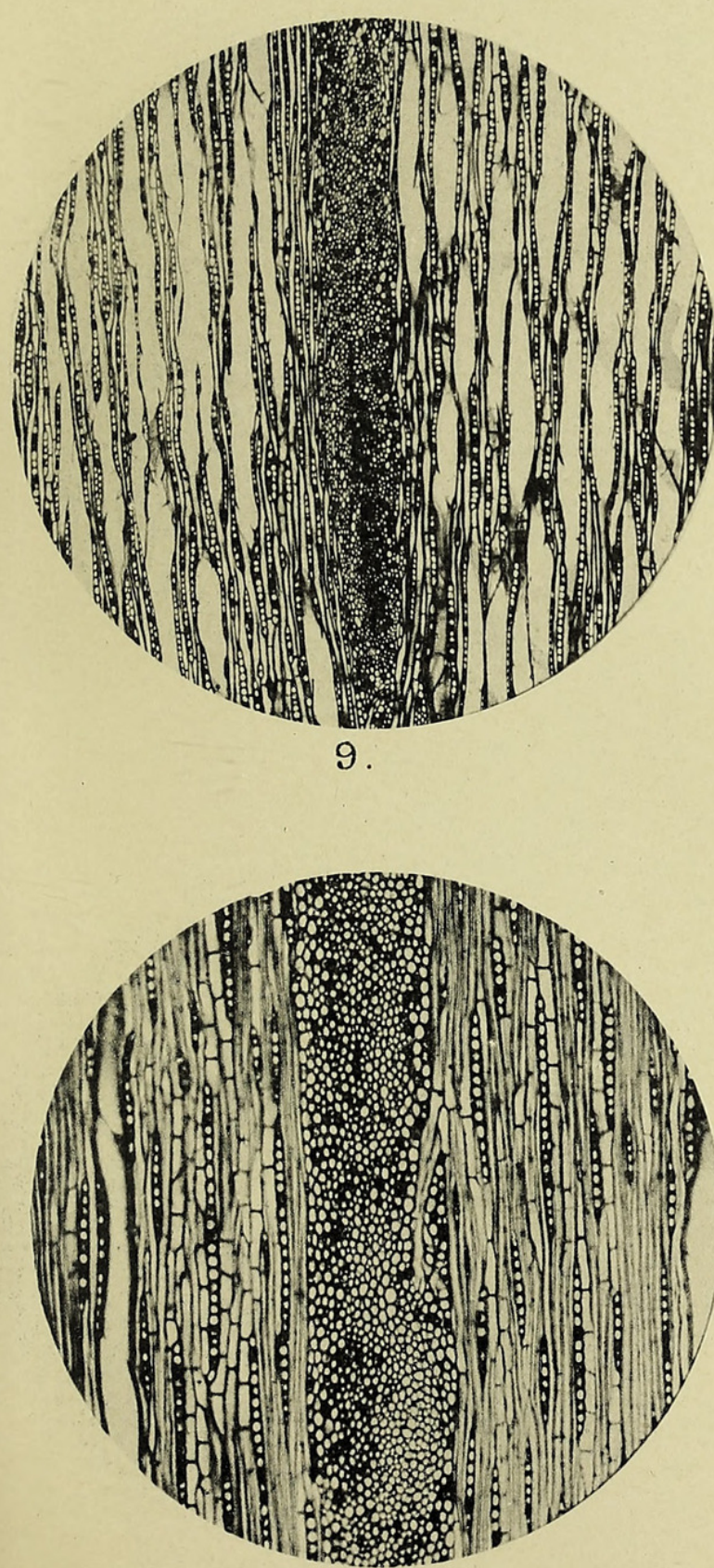

11.

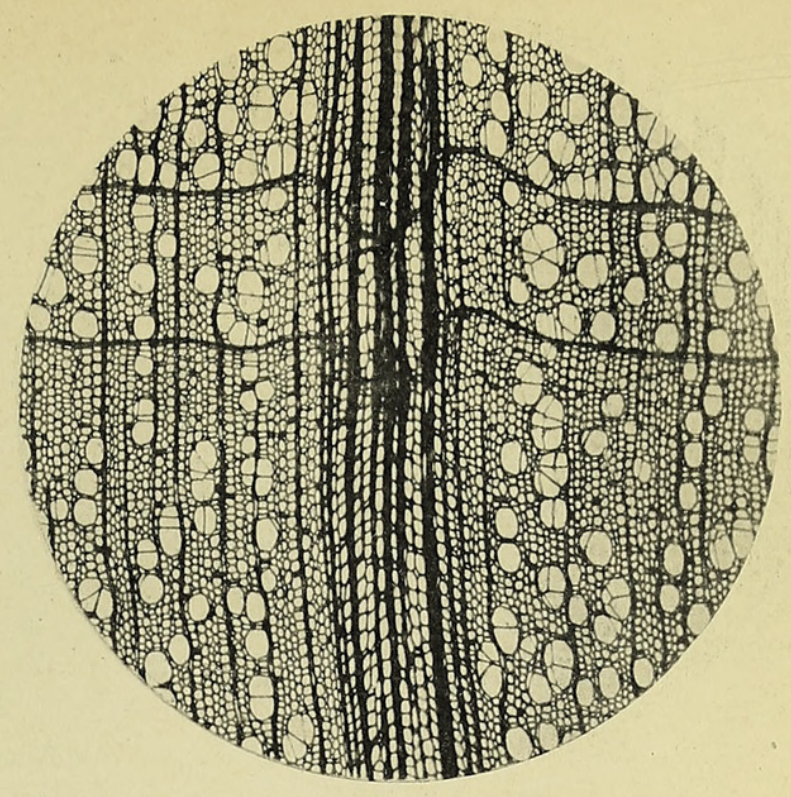

8.
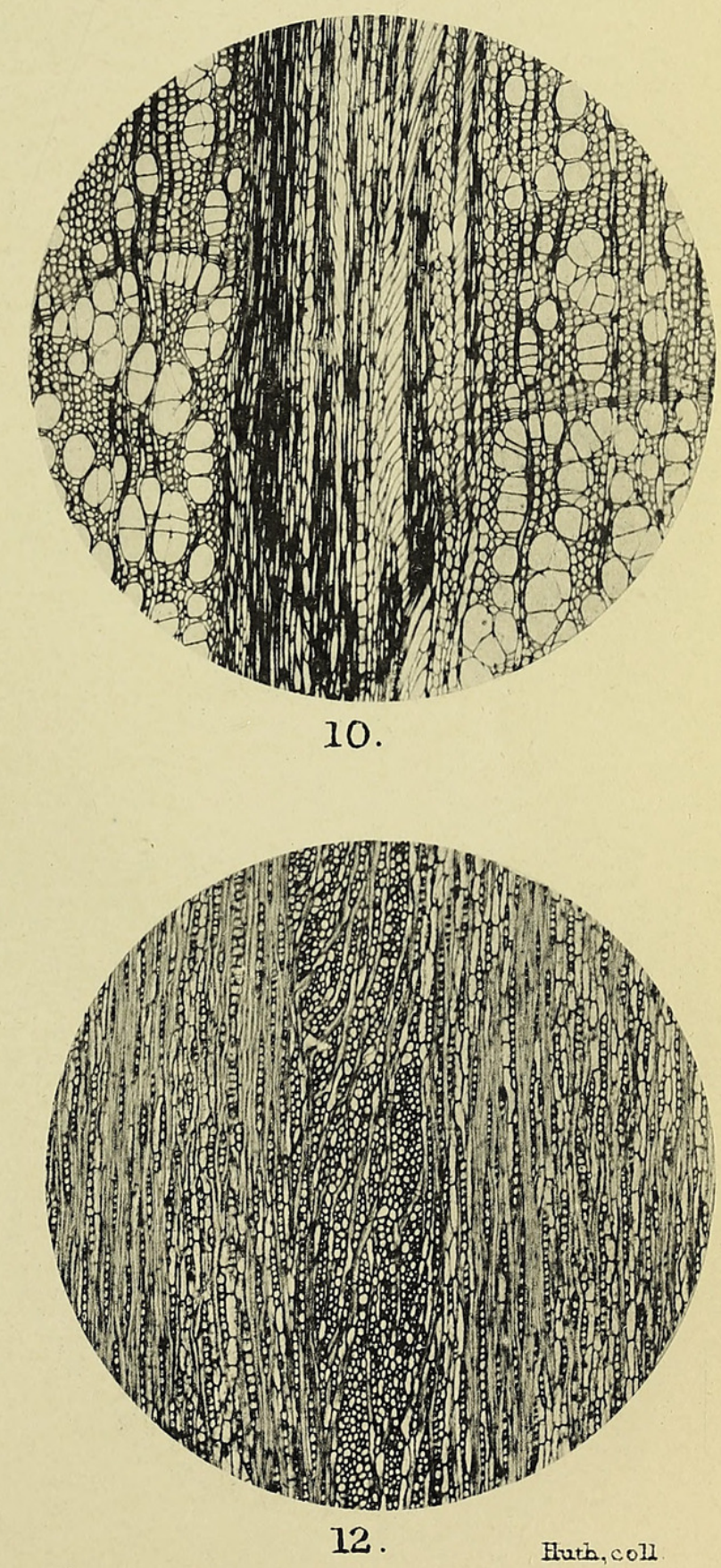
Annals of Botany.

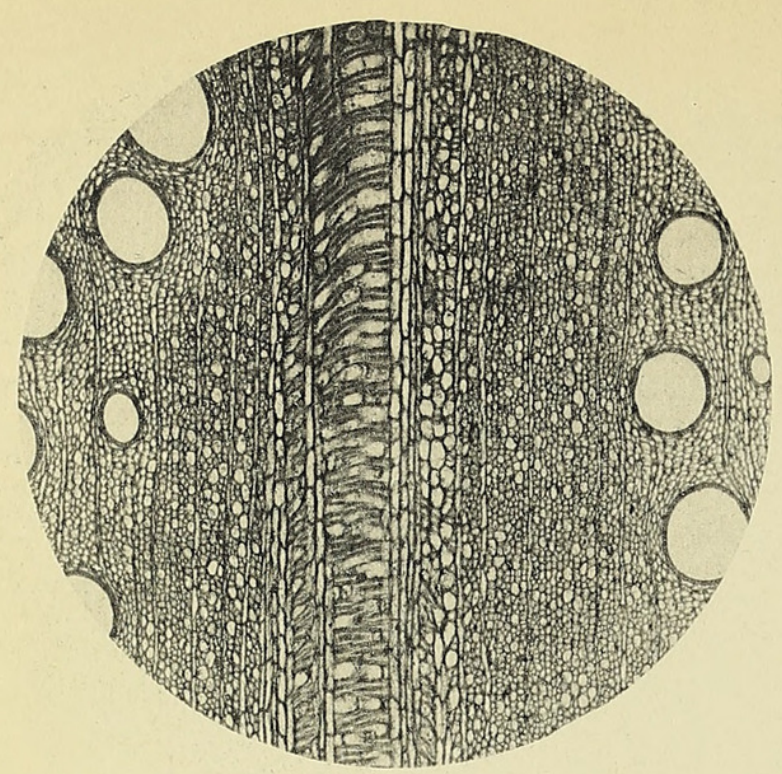

13.

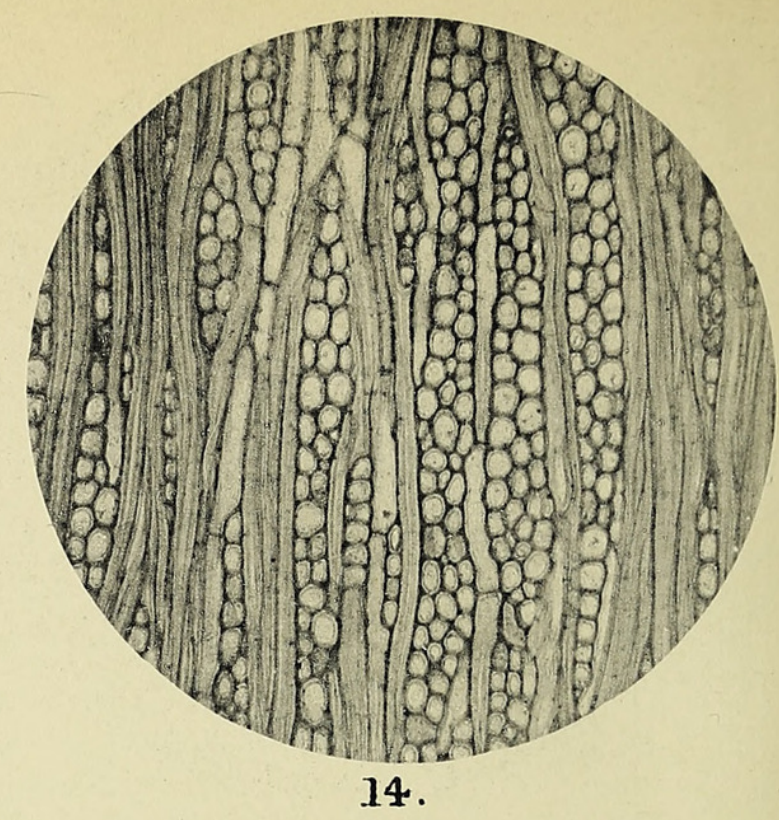

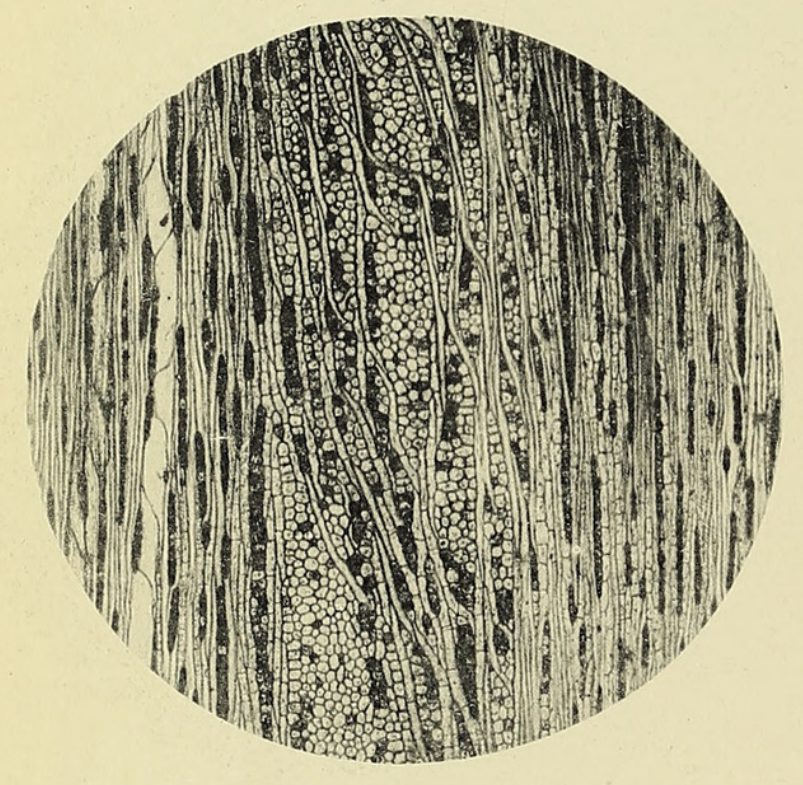

15
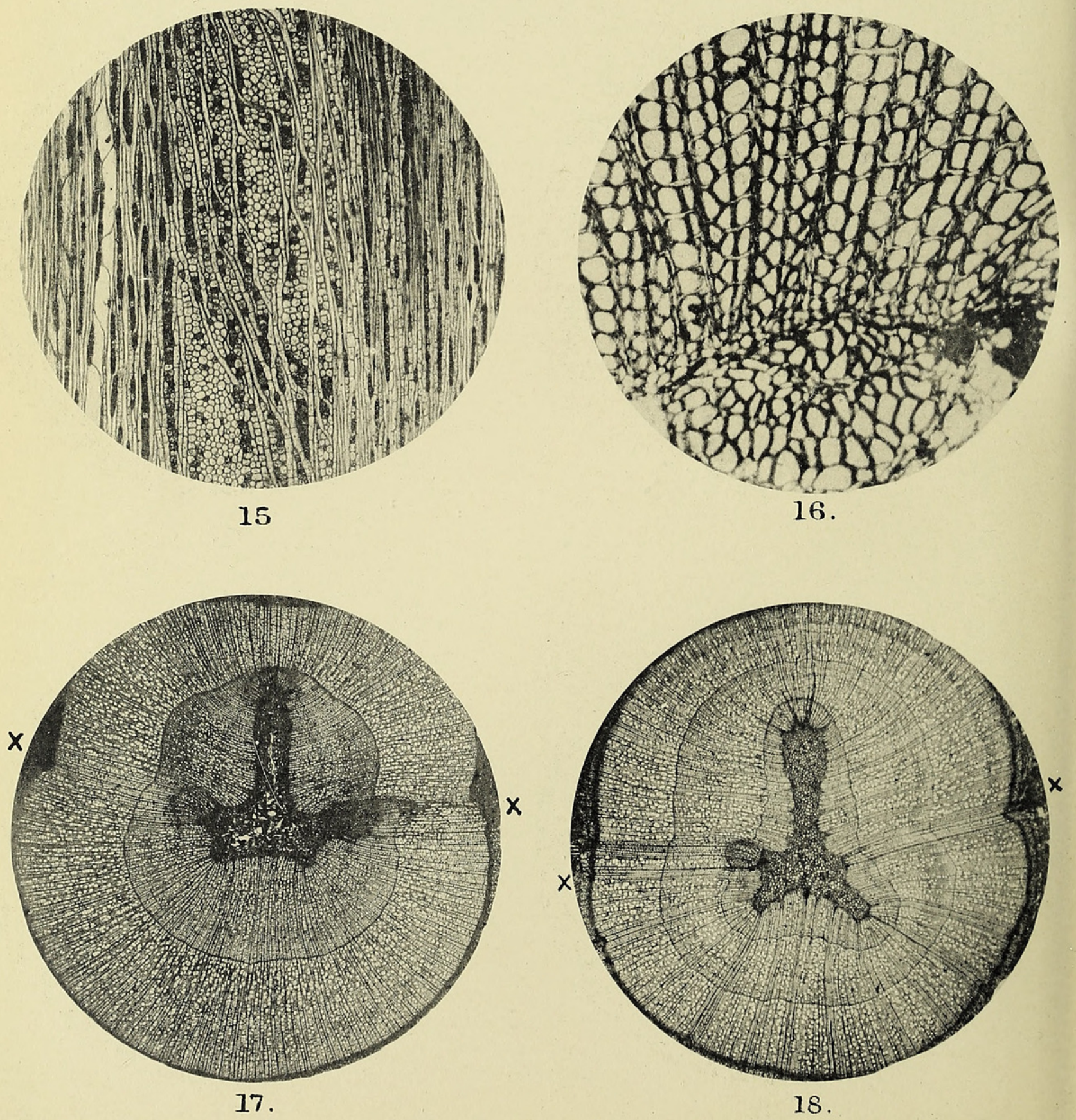

BAILEY - COMPOUND RAYS IN DICOTYLEDONS. 

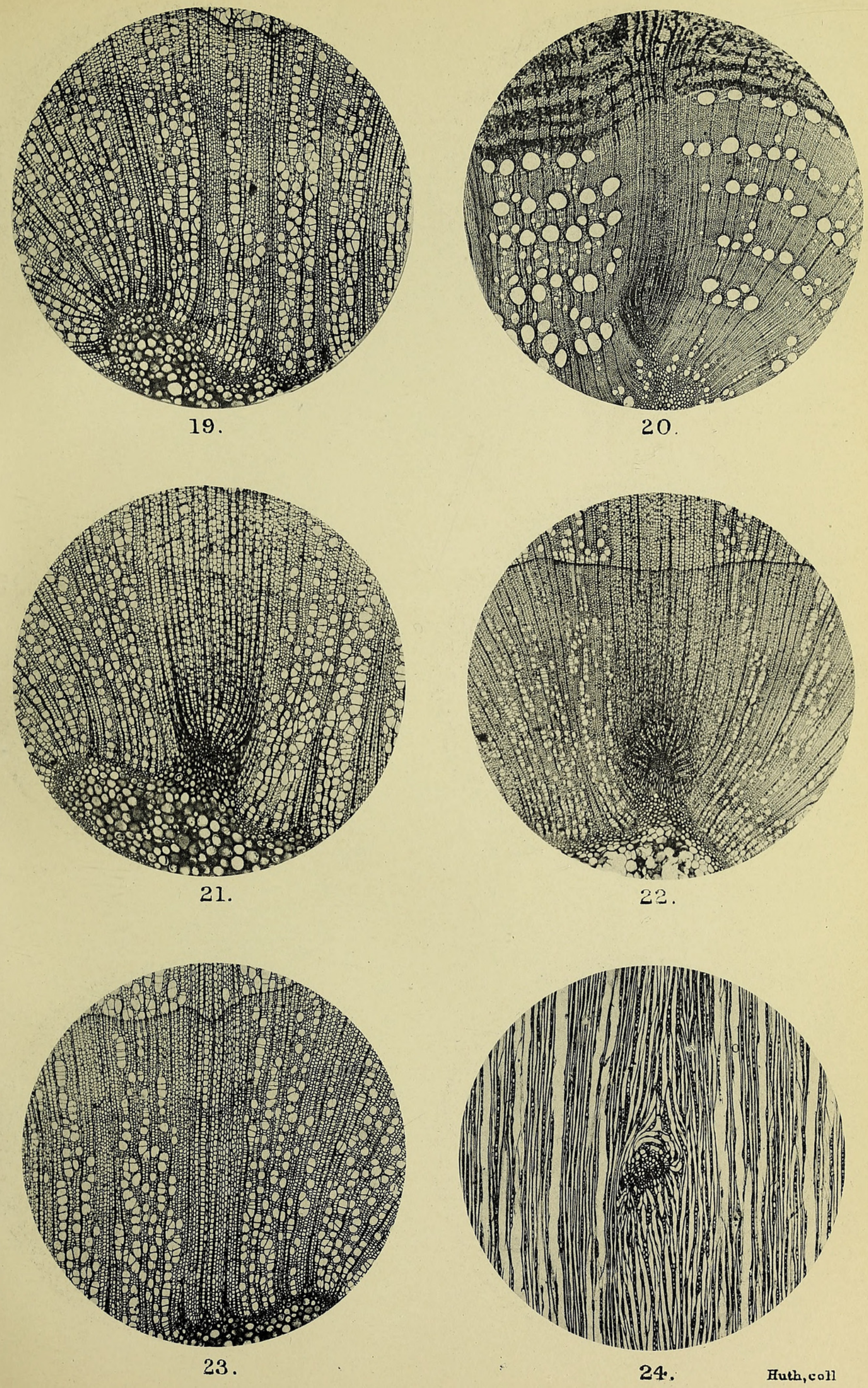


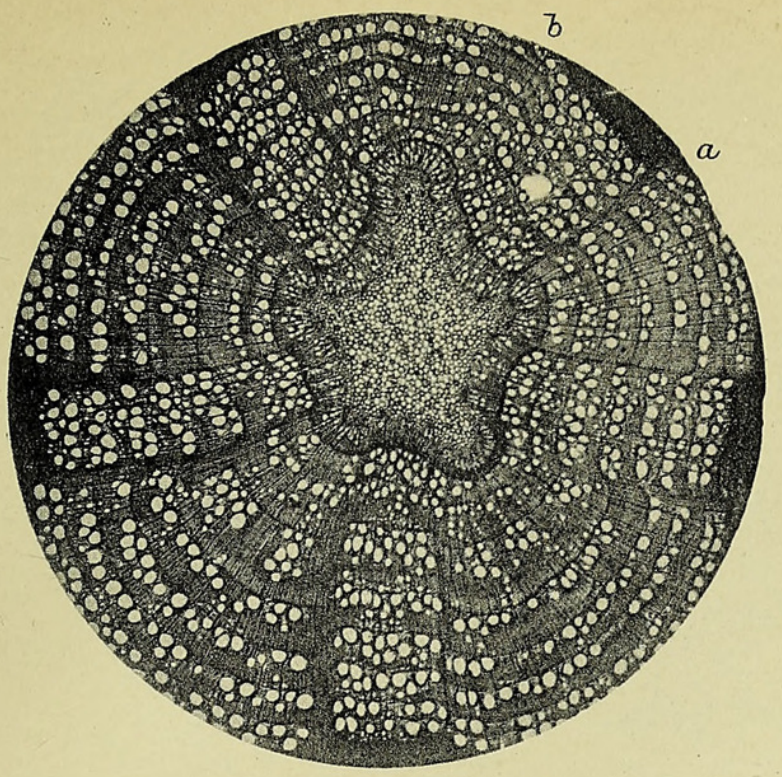

25.

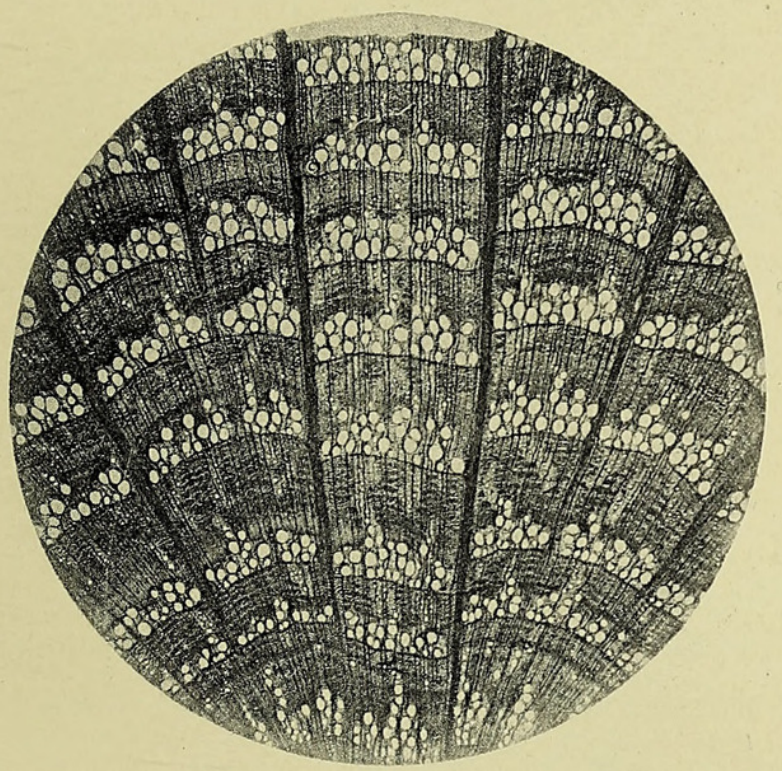

27.

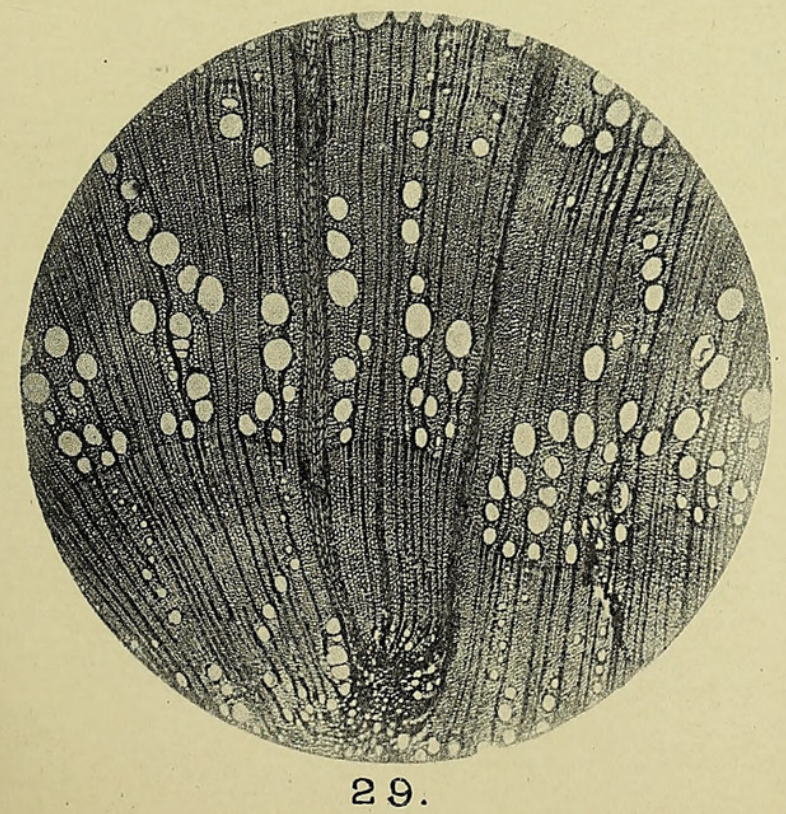

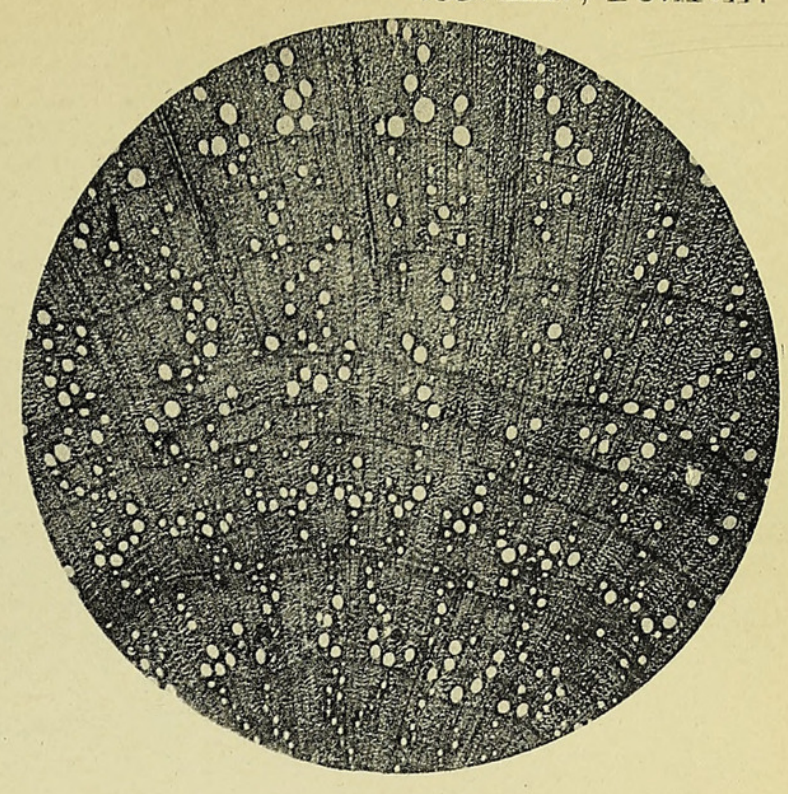

26 .

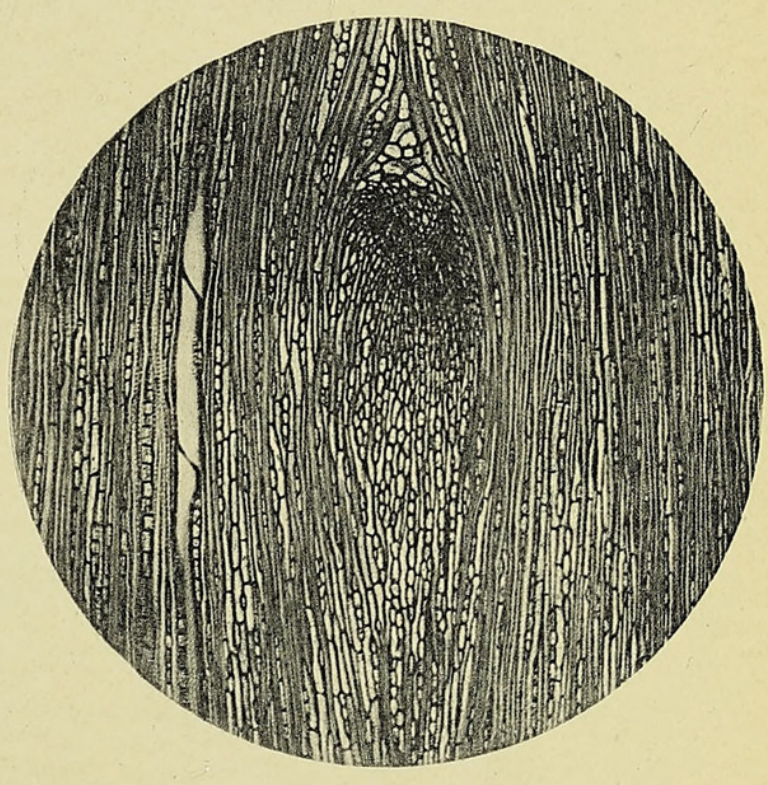

28.

BAILEY - COMPOUND RAYS IN DICOTYLEDONS. 


\section{$2 \mathrm{BHL}$ Biodiversity Heritage Library}

Bailey, Irving W. 1911. "The relation of the leaf-trace to the formation of compound rays in the lower dicotyledons." Annals of botany 25, 225-241. https://doi.org/10.1093/oxfordjournals.aob.a089316.

View This Item Online: https://www.biodiversitylibrary.org/item/236971

DOI: https://doi.org/10.1093/oxfordjournals.aob.a089316

Permalink: https://www.biodiversitylibrary.org/partpdf/319825

\section{Holding Institution}

Smithsonian Libraries

\section{Sponsored by}

Biodiversity Heritage Library

\section{Copyright \& Reuse}

Copyright Status: Not in copyright. The BHL knows of no copyright restrictions on this item.

This document was created from content at the Biodiversity Heritage Library, the world's largest open access digital library for biodiversity literature and archives. Visit BHL at https://www.biodiversitylibrary.org. 